\title{
Influenza A (H1N1) was not associated with obesity in pregnant women living in Toluca, México
}

\section{La Influenza A (H1N1) no se asoció con la obesidad en mujeres embarazadas en Toluca, México}

\author{
Hugo Mendieta-Zerón ${ }^{1,2}$, Jonnathan G. Santillán-Benítez ${ }^{1}$, María del Carmen \\ Colín-Ferreira $^{1}$, Angela Montenegro-Cárdenas ${ }^{1}$, Cynthia N. Núñez-Delira ${ }^{3}$ \\ and Gabriel G. Huitrón-Bravo ${ }^{1}$
}

\begin{abstract}
1 Molecular Biology Laboratory, Medical Research Center (CICMED), Autonomous University of the State of Mexico (UAEMex) Toluca, México.redcicmed@uaemex.mx, mezh_74@yahoo.com 2 Materno Perinatal Hospital "Monica Pretelini” (HMPMP); Asociación Científica Latina (ASCILA). Toluca, México. asociacioncientificalatina@yahoo.com.mx

3 State Health Laboratory. Health Institute of the State of Mexico (ISEM), Toluca, Mexico.
\end{abstract}

Received $3^{\text {th }}$ April 2011/Sent for Modification $5^{\text {th }}$ December 2011/Accepted $20^{\text {th }}$ December 2011

\section{ABSTRACT}

Objective The aim was to verify whether being overweight could have played a critical role in cases of mortality caused by influenza A ( $\mathrm{H} 1 \mathrm{~N} 1)$ in pregnant women. This virus' prevalence was also analyzed among people suffering from acute respiratory disease being attended at the state of Mexico's Autonomous University's medical research centre.

Methods The clinical files of women having influenza A (H1N1) attending the Monica Pretelini maternal-perinatal hospital's (HMPMP) intensive care unit in Toluca, Mexico, were reviewed. According to international recommendations, clinical detection of possible new cases of this disease was kept an open as a second step.

Results Five women suffering influenza A ( $\mathrm{H} 1 \mathrm{~N} 1)$ was attended at HMPMP's intensive care unit during 2009; only one survived. No differences in body mass index were found when comparing the anthropometric characteristics to another group of women affected by acute respiratory diseases; in fact, this parameter was below the limits for being overweight in both cases. No new case of influenza $A$ (H1N1) was found after the first eight months of 2010.

Discussion It could not be verified whether being overweight was a factor of higher mortality due to influenza A (H1N1) amongst pregnant women in the state of Mexico. The key to better survival for pregnant women hospitalized with influenza A (H1N1) seemed to be early treatment with oseltamivir. The cases decreased dramatically after the severe wave of the new pandemic due to unknown reasons. 
Key Words: Acute respiratory distress syndrome, body mass index, influenza A (H1N1), oseltamivir (source: MeSH, NLM).

\section{RESUMEN}

Objetivo Nuestro objetivo fue verificar si en los casos de mortalidad por influenza A (H1N1) en mujeres embarazadas, el sobrepeso tuvo un papel fundamental. También hemos analizado la prevalencia de este virus entre personas con enfermedad respiratoria aguda atendidas en el Centro de Investigación en Ciencias Médicas de la Universidad Autónoma del Estado de México.

Métodos Se revisaron los expedientes clínicos de las mujeres con influenza A (H1N1) atendidos en la Unidad de Cuidados Intensivos Obstétricos del Hospital Materno Perinatal, Toluca, México. De acuerdo con las recomendaciones internacionales, como segunda etapa se mantuvo un programa de detección de este virus en la población general.

Resultados Hubo cinco embarazadas con influenza A (H1N1), durante el año 2009 , de las cuales sólo una sobrevivió. Al comparar las características antropométricas con otro grupo de mujeres afectadas por enfermedades respiratorias agudas no encontramos diferencias en el índice de masa corporal. De hecho, en ambos casos, este parámetro fue inferior a los límites de sobrepeso. Después de los primeros ocho meses del año 2010 no se encontraron nuevos casos de influenza A (H1N1).

Discusión No hemos podido verificar que el sobrepeso sea un factor de mayor mortalidad en casos de infección por influenza A (H1N1) entre las mujeres embarazadas del Estado de México. La clave para una mejor supervivencia en mujeres embarazadas hospitalizadas con influenza $A(\mathrm{H} 1 \mathrm{~N} 1)$ parece ser el tratamiento precoz con Oseltamivir. Por razones desconocidas después de la ola severa de la nueva pandemia los casos disminuyeron.

Palabras Clave: Índice de masa corporal, síndrome de distrés respiratorio agudo, influenza A (H1N1), Oseltamivir (fuente: DeCS, BIREME).

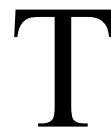
he World Health Organization (WHO) has estimated that about half of hospitalized patients (two thirds of patients admitted to an intensive care unit (ICU)) have one or more underlying medical conditions (1); however, relatively few studies have examined the risk factors associated with a severe outcome in persons infected with influenza A (H1N1) $(2,3)$. The WHO has identified the following groups as having elevated higher risk of complicated disease (children's risk groups excluded): pregnant women, persons of any age suffering chronic pulmonary/cardiac/renal/hepatic disease, metabolic disorders (e.g. diabetes), certain neurological conditions, hemoglobinopathies, immune suppression and people aged 65 and over (4). 
Pregnancy substantially increases the risk of severe respiratory illness and excessive deaths during pandemics and seasonal influenza (5). In fact, pregnant women are about three times more likely to be admitted to hospital suffering H1N1 infection than similarly aged non-pregnant women (6).

Several countries reported courses involving severe progressive pneumonia during the pandemic $(7,8)$. Australia and New Zealand reported an unusual number of young patients suffering from acute respiratory distress syndrome (ARDS) who required extracorporeal membrane oxygenation (ECMO) (9). Death rates due to A (H1N1) associated pneumonia based on these reports have varied from $14.3 \%$ (10) to $39 \%(11)$.

The Mónica Pretelini maternal-perinatal hospital (HMPMP) is the most specialized public medical unit dedicated to attending risky pregnancies in the state of Mexico, Mexico.

As published previously, pandemic H1N1 influenza should be considered in the differential diagnosis of any respiratory illness whilst a pandemic virus is circulating in a particular community (12). Fortunately, a molecular biology laboratory was installed at the Autonomous University of the state of Mexico's (UAEMex) Medical Research Centre (CICMED) which began operating in November 2009, 300 meters away from HMPMP; it was committed to offering research support in the event of an outbreak of influenza.

\section{METHODS}

Design

This was a comparative, descriptive, cross-sectional study. A first step involved a retrospective study of positive cases of influenza A (H1N1) who died in the HMPMP 's ICU. All patients were suffering from acute respiratory illness and pandemic H1N1 infection confirmed by real-time reverse-transcriptase polymerase chain reaction (RT-PCR). Cases of death caused by influenza A (H1N1) were compared to an equal number of cases of mortality in similarly aged people which were not attributed to influenza-associated ARDS. 
Open clinical detection of influenza A (H1N1) was developed at CICMED, UAEMex, as a second step after the last reported death of influenza A (H1N1) in 2009. The research team underwent a training course at the Institute of Diagnosis and Epidemiological Reference (InDRE), Mexico, DF, to develop these phases.

A standardised computer-based form was completed by the researchers; it included demographic data, underlying medical conditions, clinical signs, symptoms, treatment and outcomes.

\section{Setting}

The study was conducted at HMPMP serving a population of around 200,000 women; the ICU attends at least one woman per day with pregnancy-related complications.

Data collection

Data was extracted from the clinical files, including demographic characteristics, past medical history, pre-hospital medication, clinical presentation, care timelines and initial assessment. Height (taken with a measuring tape) and weight (measured with a Hill-Rom, Total Care, electric bed) were recorded at the ICU. Chest X-rays, laboratory tests and other investigations were performed as mandated by clinical condition.

The symptoms and personal information of patients having flu-like symptoms who attended CICMED were recorded according to influenza epidemiological vigilance system (SISVEFLU) guidelines and throat swabs were taken. Viral RNA was extracted with a MagNA Pure LC 2.0 instrument and a Roche RealTime ready influenza A (H1N1) detection set with simultaneous PCR detection of influenza A; the specific pandemic $\mathrm{H} 1$ gene was used.

Data analysis

Data was analyzed using SPSS Version 16. The Mann Whitney U test was used for continuous variables.

This study followed the Helsinki recommendations (13) and was approved by CICMED ethics and research committee. 


\section{RESULTS}

A total of 5 patients suffering influenza $A(\mathrm{H} 1 \mathrm{~N} 1)$ infection were identified in 113 patients hospitalized at the HMPMP's ICU from September to December 2009. Four of these patients had arrived still pregnant at other state of Mexico's health institute (ISEM) hospitals (Figure 1) and had then been referred to HMPMP; the fifth case was attended at HMPMP since the beginning.

Of the four deaths, one was still pregnant when arriving at HMPMP while the other three were in puerperium. The fifth positive case was the only one who survived and was still pregnant when she arrived at HMPMP.

Figure 1. Places of first medical attention for cases of death in pregnant women

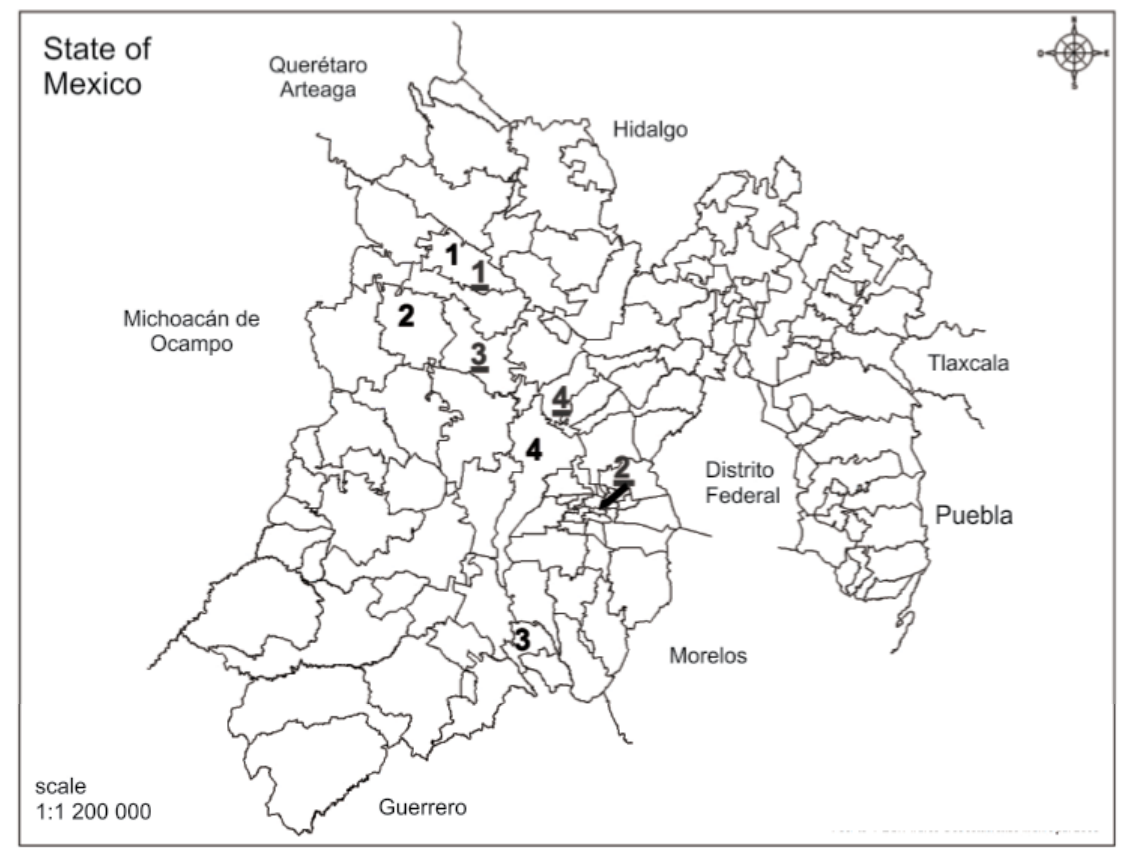

Bold numbers: influenza A (H1N1); Numbers in gray: acute respiratory distress syndrome (ARDS) non-influenza positive; The Monica Pretelini maternal-perinatal hospital is located in the City of Toluca (number 4 in black), Capital of the state of Mexico.

Table 1 shows laboratory results on entry. Most patients had lymphopenia 


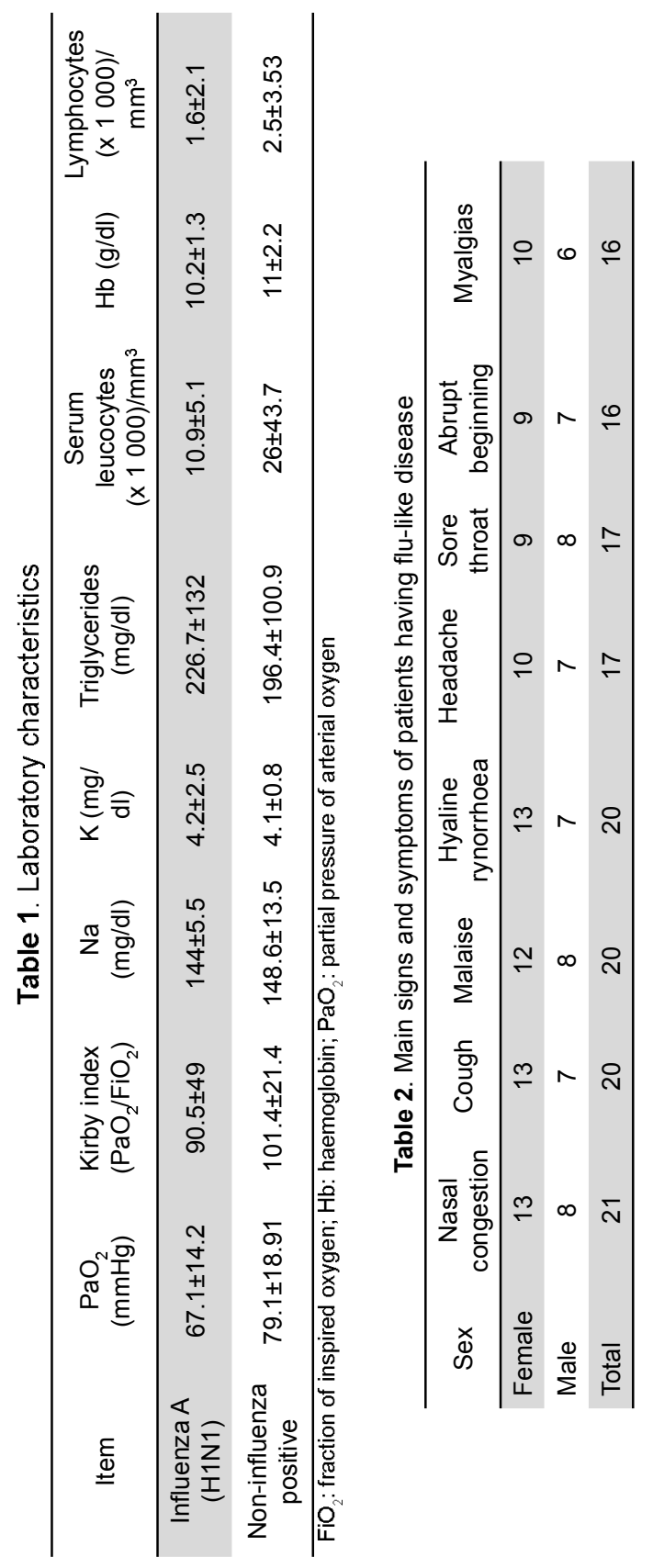


Preadmission care

Mean interval between onset of illness and admission recorded for the five cases of H1N1 infection was $4.2 \pm 2.94$ days; it was shorter in the group of deaths not attributed to influenza A (H1N1): $3.25 \pm 2.87$ days.

Clinical presentation

The three influenza A (H1N1) patients who died arrived at our medical unit already intubated; the fourth case was intubated in the ICU as a result of her deterioration. Only one woman ( $20 \%$ of influenza positive cases) had gestational diabetes mellitus. No other concomitant chronic diseases were diagnosed, such as hypertension.

Anthropometric characteristics

The cases' mean age was $25.8 \pm 9.25$ years in the influenza group and $28 \pm 7.87$ years in women who were non-positive for influenza. Being overweight was detected in two patients having influenza and in one patient without this disease. Obesity, defined as $>30 \mathrm{~kg} / \mathrm{m}^{2}$ body mass index (BMI), was not present in any group.

Arterial blood gas

Analysis readings revealed a significant statistical difference in arterial oxygen $\left(\mathrm{PaO}_{2}\right)$ partial pressure and Kirby index $\left(\mathrm{PaO}_{2} /\right.$ fraction of inspired oxygen $\left.\left(\mathrm{FiO}_{2}\right)\right),(\mathrm{p}<0.05)$ this being worse in women who died from influenza $\mathrm{A}(\mathrm{H} 1 \mathrm{~N} 1)$.

Length of stay

Mean hospital stay was $23.6 \pm 8.56$ days in women with the new virus and $5.25 \pm 3.59$ days in women who died from non-influenza positive lung diseases.

Infections

Co-infection involved Escherichia coli (3), Staphylococcus sp. (1), Staphylococcus coagulase negative (1), Pseudomona (3) and Candida (2).

Inpatient treatment

Antiviral drugs were prescribed for the five patients suffering influenza immediately after their admission.

Results of open clinical detection

Twenty-six highly suspicious cases for this disease were analyzed after 
eight months of a strategy for detecting H1N1 (17 women and 9 men, mean age $31.2 \pm 12.1$ years). The main signs and symptoms are listed in Table 2 . Only two cases (both women) were positive for seasonal influenza.

\section{DISCUSSION}

This study has considered that articles focusing on pregnant women suffering from influenza A (H1N1) report too few numbers; for example, only seven were reported by the H1N1 SEMICYUC working group (14) which took papers by Rello et al., and Raffo et al., into account $(8 ; 15)$. Thirty adult pregnant women tested positive for pandemic H1N1 2009 virus in a previous study in Canada; six of these women were admitted to the ICU and two patients died while in the ICU, despite the fact that all patients received oseltamivir and that non-conventional ventilatory support such as high frequency ventilation or ECMO was available (16). There was no description of a relationship between BMI and clinical evolution in pregnant women suffering pandemic H1N1 in the largest case series published to date (17). The present study reports five cases of pregnant women infected with influenza A (H1N1), one of whom was treated with ECMO which was not mentioned as therapeutic management in the series analyzed by the H1N1 SEMICYUC working group.

The patients' geographical origin did not seem to be critical for the worst prognosis, as the distance between the HMPMP and the referral hospitals is no more than two hours far away by car or $20 \mathrm{~min}$ by state of Mexico emergency system (SUEM) helicopter.

Mean interval between illness onset and hospital admission was just 1 day in children and 2 days in adults in a previous report (18), while a wide range (1 to 7 days) was detected in our work, even though having no statistical difference. Although oseltamivir was administered to the five influenza patients on entry to the ICU, it was already too late to reverse lung damage, as demonstrated by blood gas parameters $\left(\mathrm{PaO}_{2}\right.$ and Kirby index). Three of them had already presented influenza symptoms for a mean six days. Unfortunately, ARDS is accompanied by severe hypoxemia, with extensive tissue damage caused by the virus, characterized by necrotizing bronchiolitis, neutrophilic infiltrate, diffuse alveolar damage and hyaline membrane formation (19). 
As previously noted, the clinical and radiological manifestations caused by the influenza virus are not specific. In this regard, a differential diagnosis thus includes infection with other viruses and bacteria, such as respiratory syncytial virus, coronavirus, parainfluenza, rhinovirus, adenovirus and Mycoplasma sp (20). The most common coinfections in the present study were Escherichia coli and Pseudomona in three patients.

It was also noted that the influenza group's longer stay was partly attributed to the medical management of the one patient with ECMO (21); to the best of our knowledge, this was the only hospital in Mexico that offered this option during the health crisis that affected Mexico.

Using this approach meant that being overweight could not be verified as being a factor of higher mortality due to influenza A (H1N1) among pregnant women in the state of Mexico. Clearly, the key for better survival in hospitalized pregnant women suffering influenza A (H1N1) seemed to be early treatment with an antiviral option.

Unexpectedly, no positive case for this pandemic was indentified in an open population having flu-like symptoms after the highest worldwide peak of influenza A (H1N1) incidence (22).

Of particular concern for the future regarding a new influenza outbreak, it is suggested that new strategies such as human monoclonal antibodies obtained from influenza survivors should be developed, as well as existing antiviral chemotherapeutics (23)

Acknowledgments: The authors would like to thank the medical staff of the Mónica Pretelini maternal-perinatal hospital's obstetrical intensive care unit.

Funding: Funding was received from the International Federation of Clinical Chemistry and Laboratory Medicine (IFCC).

Competing Interests: None declared.

\section{REFERENCES}

1. WHO. Clinical features of severe cases of pandemic influenza. [Internet]. Available at: http://www.who.int/csr/disease/swineflu/notes/h1n1_clinical_features_20091016/ en/index.html. Consulted March 2011. 
2. Jain S, Kamimoto L, Bramley AM, Schmitz AM, Benoit SR, Louie J, et al. Hospitalized patients with $2009 \mathrm{H} 1 \mathrm{~N} 1$ influenza in the United States, April-June 2009. N Engl J Med. 2009;361:1935-44.

3. Louie JK, Acosta M, Winter K, Jean C, Gavali S, Schechter R, et al. Factors associated with death or hospitalization due to pandemic 2009 influenza $A(H 1 N 1)$ infection in California. JAMA. 2009;302:1896-902.

4. Bertisch B, Vernazza P, Boggian K. Patients with influenza A/H1N1v- associated pneumonia: the perspective of a tertiary care hospital in Switzerland. Swiss Med Wkly. 2010;140:w13069.

5. Fiore AE, Shay DK, Broder K, Iskander JK, Uyeki TM, Mootrey G, et al. Prevention and control of seasonal influenza with vaccines: recommendations of the Advisory Committee on Immunization Practices (ACIP), 2009. MMWR Recomm Rep. 2009;58:1-52.

6. Zaman K, Roy E, Arifeen SE, Rahman M, Raqib R, Wilson E, et al. Effectiveness of maternal influenza immunization in mothers and infants. N Engl J Med. 2008;359:1555-64.

7. Gómez-Gómez A, Magaña-Aquino M, García-Sepúlveda C, Ochoa-Pérez UR, FalconEscobedo R, Comas-García A, et al. Severe pneumonia associated with pandemic (H1N1) 2009 outbreak, San Luis Potosi, Mexico. Emerg Infect Dis. 2010;16:27-34.

8. Rello J, Rodríguez A, Ibañez P, Socias L, Cebrian J, Marques A, et al. Intensive care adult patients with severe respiratory failure caused by Influenza A (H1N1)v in Spain. Crit Care. 2009;13:R148.

9. Davies A, Jones D, Bailey M, Beca J, Bellomo R, Blackwell N, et al. Extracorporeal Membrane Oxygenation for 2009 Influenza A(H1N1) Acute Respiratory Distress Syndrome. JAMA. 2009;302:1888-95.

10. Kumar A, Zarychanski R, Pinto R, Cook DJ, Marshall J, Lacroix J, et al. Critically ill patients with 2009 influenza A(H1N1) infection in Canada. JAMA. 2009;302:1872-9.

11. Pérez-Padilla R, de IR-Z, Ponce de LS, Hernández M, Quinones-Falconi F, Bautista $E$, et al. Pneumonia and respiratory failure from swine-origin influenza $A(H 1 N 1)$ in Mexico. N Engl J Med. 2009;361:680-9.

12. Nguyen-Van-Tam JS, Openshaw PJ, Hashim A, Gadd EM, Lim WS, Semple MG, et al. Risk factors for hospitalisation and poor outcome with pandemic $\mathrm{A} / \mathrm{H} 1 \mathrm{~N} 1$ influenza: United Kingdom first wave (May-September 2009). Thorax. 2010;65:645-51.

13. WMA Declaration of Helsinki - Ethical Principles for Medical Research Involving Human Subjects. [Internet]. Available at: http://www.wma.net/en/30publications/10policies/ b3/index.html. Consulted March 2011.

14. Rodríguez A, Socias L, Guerrero JE, Figueira JC, González N, Maravi-Poma E, et al. [Pandemic influenza $A$ in the ICU: experience in Spain and Latin America. GETGAG/SEMICYUC/(Spanish Working Group on Severe Pandemic Influenza A/ SEMICYUC)]. Med Intensiva. 2010;34:87-94.

15. Raffo L. [Influenza $A(\mathrm{H} 1 \mathrm{~N} 1)$ epidemic in Argentina. Experience in a National General Hospital (Hospital Nacional Alejandro Posadas)]. Medicina (B Aires). 2009;69:393423.

16. Oluyomi-Obi T, Avery L, Schneider C, Kumar A, Lapinsky S, Menticoglou S, et al. Perinatal and maternal outcomes in critically ill obstetrics patients with pandemic H1N1 Influenza A. J Obstet Gynaecol Can. 2010;32:443-52.

17. Lim ML, Lim WY, Tee NW, Lim SH, Chee JJ. Obstetric outcomes of influenza A H1N1 (2009) infection in pregnancy--experience of a Singapore tertiary hospital. Ann Acad Med Singapore. 2010;39:295-4.

18. Nguyen-Van-Tam JS, Openshaw PJ, Hashim A, Gadd EM, Lim WS, Semple MG, et al. Risk factors for hospitalisation and poor outcome with pandemic $\mathrm{A} / \mathrm{H} 1 \mathrm{~N} 1$ influenza: United Kingdom first wave (May-September 2009). Thorax. 2010;65:645-51. 
19. Pérez-Padilla R, de IR-Z, Ponce de LS, Hernández M, Quinones-Falconi F, Bautista E, et al. Pneumonia and respiratory failure from swine-origin influenza $A(H 1 N 1)$ in Mexico. N Engl J Med. 2009;361:680-9.

20. Health Establishments Preparation for Unusual or Unexpected Cases or Clusters of Severe Acute Respiratory Infection (SARI). [Internet]. Available at: http://www. influenzatraining.org/documents/s16036e/s16036e.pdf. Consulted March 2011.

21. Vázquez de Anda G.F, Montenegro Cárdenas A. Experience from the 2009 Influenza Outbreak in Mexico: One year later. ICU Management. 2010;10:28-30.

22. Instituto de Salud Carlos III.Centro Nacional de Epidemiología.Boletín Epidemiológico Semanal en Red. Informe semanal del 22 de febrero de 2010. Informe Semanal relativo a las Enfermedades de Declaración Obligatoria. España. [Internet]. Available at: http://www.isciii.es/htdocs/centros/epidemiologia/boletin_red/IS100222-WEB.pdf. Consulted March 2011.

23. Kashyap AK, Steel J, Rubrum A, Estelles A, Briante R, llyushina NA, et al. Protection from the $2009 \mathrm{H} 1 \mathrm{~N} 1$ pandemic influenza by an antibody from combinatorial survivorbased libraries. PLoS Pathog. 2010;6:e1000990. 